\title{
The Influence Of Annona Muricata Leaves Extract In Damaging Kidney Cell And Inducing Caspase-9 Activity
}

\author{
Azim Yahia M.Dayeef ${ }^{1}$,Setyawati Karyono ${ }^{2}$,Hidayat Sujuti ${ }^{3}$ \\ ${ }^{I}$ Student of Master Program, Department of toxicology, Faculty of medicine, Brawijaya \\ University, Malang, Indonesia \\ ${ }^{2}$ Department of pharmacology, Faculty of medicine, Brawijaya University, Malang, Indonesia \\ ${ }^{3}$ Department of Biochemistry, Faculty of medicine, Brawijaya University, Malang, Indonesia
}

\begin{abstract}
Annona muricata leaf extract is used in Indonesia traditional medicine for the treatment of many disease. Work done has demonstrated Annona muricata to be effective in treating carbon tetrachloride-and acetaminophen-induced hepatic damage, In this present study, the efficacy of ethanolic extracts of Annona muricata leaves for its cytotoxicity potential and induction of apoptosis in tubular cells, was investigated. Phytochemical screening verified presence of alkaloids, tannins, flavonoids, saponins, anthraquinones and cardiac glycosides. The present study was undertaken to investigate the leaf extract effects of Annona muricata Linn. on the level of serum creatinine and damage of tubular cell structure that effect of kidney cell functions and caspase-9 expression in glomerulus and tubular cells. The animals $(n=20)$ Were grouped a (control), I, II, AND III (experimental). The experimental animals of group I were administered with $10 \mathrm{mg} / \mathrm{kg}$ body weight/ day annona muricata extract in saline for 40 days, group II were administered with $20 \mathrm{mg} / \mathrm{kg}$ body weight/ day annona muricata extract in saline for 40 days and III were administered with $40 \mathrm{mg} / \mathrm{kg}$ body weight/day annona muricata extract in saline for 40 days and then we see the effect on creatinine serum concentration by ELISA method and glomerulus,tubular cells were fixed and processed to examine the histological changes and caspase-9 expression in glomerulus and tubular cells.
\end{abstract}

Keywords : Immunohistochemistry, Annona muricata extract, toxicity, creatinine serum concentration, glomerulus and tubular cells on caspase-9

\section{Introduction}

The use of complementary traditional medicine which include herbal medicines in the treatment of various diseases has expanded rapidly in both developed and developing countries, attributable to affordability, accessibility and efficacy. Documented and undocumented adverse drug reactions associated with herbal medicines makes it pertinent that pre-clinical toxicological studies be carried out on these natural products. Herbal remedies from medicinal plants have been used traditionally in many parts of the world where access to formal healthcare is limited. There are several reasons why the use of medicinal plants should be studied: herbal remedies may have recognizable therapeutic effects (Bailey and Day,1989). they may also have toxic side-effect (Keen et al; 1994). Although, the use of medicinal plants provides an indication of beliefs about illness and its treatment that may conflict with beliefs of workers in the formal healthcare system (Morgan and Watkins, 1988).

Medicinal plants and herbs contain substances known to the ancient civilizations for their healing properties. People without access to modern medicine rely on these medicinal plants and herbs for treating diseases, as they are similar in terms of active compound. Annona muricata is one of such medicinal plants. Annona muricata (Linn.) commonly called sour sop or "Apre" in the local Ghanaian Twi language, is a small erect evergreen tropical fruit tree plant belonging to the family Annonaceae, growing 5-6 meters in height. It is underutilized (ICUC, 2002) and is grown in Ghana mainly for ornamental purposes and for its fruits. The leaves of Annona muricata has been reported to contain several groups of substances collectively called annonaceous acetogenins including murihexocin and annocuricin (Kim et al., 1998), annopentocin A, B and C, (2,4-cis)annomuricin-D-one, murihexocin $\mathrm{A}$ and $\mathrm{B},(2,4$-trans)-annomuricin-D-one, 4-acetyl gigantetrocin and cisgigantrionin (Zeng et al., 1996), muricatocin A, B and C (Wu et al., 1995) and annohexocin (Zeng et al., 1996). The high potency, selectivity, wide chemical and biological diversity and effectiveness of these compounds against microbial resistance could well make them the next class of useful natural antitumor and pesticidal agents (Alali et al., 1999) and other pharmacological effects. The basic photochemical screen has revealed Annona muricata to contain saponins, glycosides, tannins and flavonoids (Arthur et al., 2011).The leaves of Annona muricata have essential oils with parasiticidal, anti-diarrheal, rheumatological and anti-neuralgic properties (Gleye et al., 1998). The boiled water infusion of the leaves have anti-plasmodic, astringent and gastric properties (Khan et al., 1997), help treat diabetes and gastric upset (Adewole and Ojewole, 2006), jaundice (Mshana et al., 2000) and used in treating kidney aliments (Duke, 1970). The leaves are also 
hepatoprotective against carbon tetrachloride and acetaminophen-induced liver damage and in streptozotocintreated diabetic rats (Adewole and Ojewole, 2008).

This study was designed to see the sub acute toxic effects of anona muricata extract on creatinine serum concentration and tubular cells, and safety of annona muricata in animals and also to carry out the preliminary phytochemical screening.

\subsection{Materials And Methods}

Adult male mice $(n=20)$, each weighing between 25-30 grams, were taken from the pharmacological laboratory in the medical faculty of Brawijaya University in Malang. The animals were divided into four groups as $\mathrm{A}, \mathrm{B}, \mathrm{C}$ and $\mathrm{D}$ each comprising of five animals. Five animals of each subgroup were kept in one cage. Animals of group A (control) were given normal saline orally for period of 40 days. The experimental animals of group B were administered with $10 \mathrm{mg} / \mathrm{kg}$ body weight/day annona muricata extract in saline for 40 days, group C were administered with $20 \mathrm{mg} / \mathrm{kg}$ body weight/day annona muricata extract in saline for 40 days and group D were administered with $20 \mathrm{mg} / \mathrm{kg}$ body weight/day annona muricata extract in saline for 40 days. after finish experiment time (40 days) we will take serum blood from mice to see the concentration of creatinine serum by ELISA method. The glomerulus and tubular cells were carefully dissected and removed. The tissues were fixed in $10 \%$ formalin, embedded in paraffin and 5 um sections were cut and stained with haematoxylin and eosin. The tissue section were observed under a research light microscope for qualitative changes in glomerulus and tubular cells and tissue also examined using Immunohistochemistry method to see the expression of caspase-9 on glomerulus and tubular cells.

\section{Result \\ 2.1 Effect Of Different Doses of Annona Muricata Ethanolic Extract on Creatinine Serum Concentration}

In the figure 1 below with increasing doses of annona muricata extract increasingly high then drop down to the more creatinine serum concentration that causes kidney damage leading to renal failure.

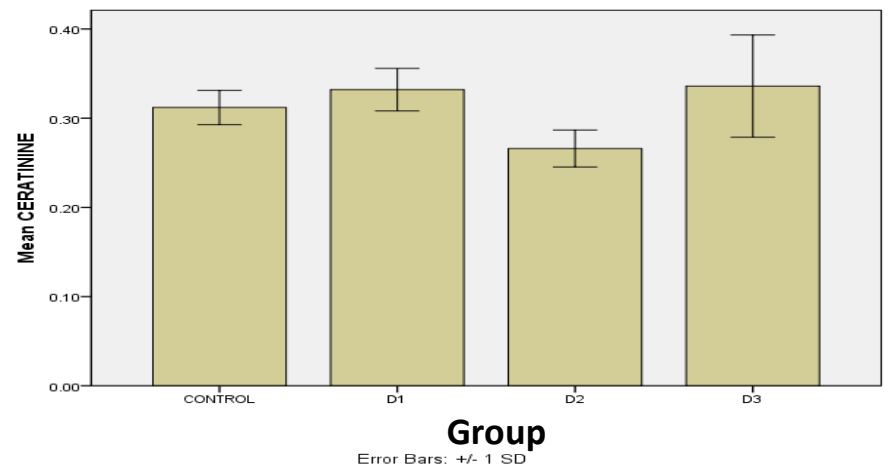

Figure 1: Bar Graph of mean of creatinine in serum mice for each group

Control : control group with normal saline

Group I : annona muricat extract with doses $10 \mathrm{mg} / \mathrm{kg} . \mathrm{bw} /$ day

Group II : annona muricat extract with doses $20 \mathrm{mg} / \mathrm{kg} . b w / \mathrm{day}$

Group III : annona muricat extract with doses $40 \mathrm{mg} / \mathrm{kg} . \mathrm{bw} / \mathrm{day}$

\subsection{Effect of dose of annona muricata extract on kidney cells (glomerulus and tubular).}

Control Group mice showing the glomerulus and tubular cells in the microscope whit out treatment by annona muricata extract, where the tubular cavity some as normal. (figure 2)

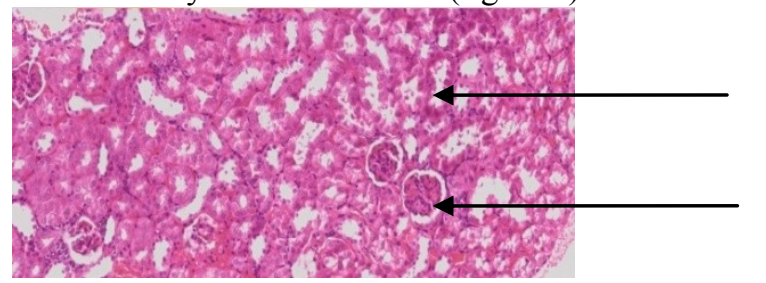

Tubular

Glomerulus

Figure 2 : normal glomerulus and tubular cavity(by microscope 100X)

Group I mice after treatment by $10 \mathrm{mg} / \mathrm{kg}$.bw/day annona muricata extract showing an shrinkage of tubular cavity if compared with the above figure of glomerulus and tubular cells whit out treatment by annona muricata extract. (figure 3) 


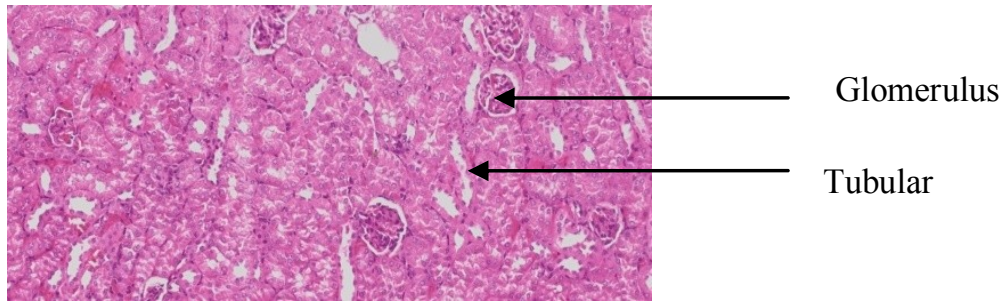

Figure 3 : effect of dose annona muricata extract in $10 \mathrm{mg} / \mathrm{kg} . b w /$ day (by microscope 100X)

Group II mice after treatment by $20 \mathrm{mg} / \mathrm{kg}$.bw/day annona muricata extract, showing the change in the concentration of annona muricata extract dosing will lead to increase damage of tubular cavity but is normal number of glomerulus cells. (figure 4)

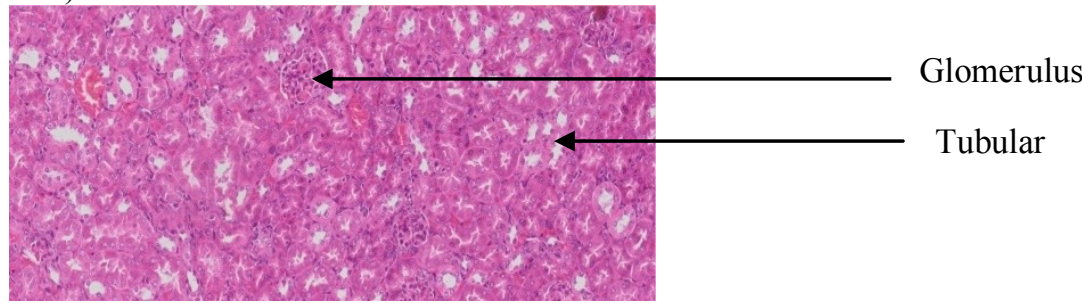

Figure 4 : effect of dose annona muricata extract in $20 \mathrm{mg} / \mathrm{kg} . b w /$ day (by microscope 100X)

Group III mice after treatment by $40 \mathrm{mg} / \mathrm{kg} . \mathrm{bw} /$ day annona muricata extract, showing more severe damage of tubular cavity. but is normal number of glomerulus cells. There for increasing dose variation would seen more suffer damage and was observed in the fourth image. were the function whit annona muricata extract dose $40 \mathrm{mg} / \mathrm{kg}$ increase damage of tubular cells number that effect of kidney cell function leading to renal failure. (figure 5)

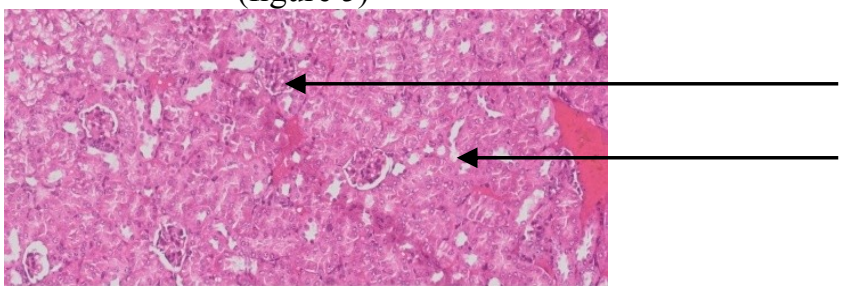

Glomerulus

Tubular

Figure 5 : effect of dose annona muricata extract in $40 \mathrm{mg} / \mathrm{kg} . b w /$ day (by microscope 100X)

\subsection{Effect of Different Doses of Annon Muricata Extract on Account Of caspase-9 in Tubular cell}

In the figure 6 below with increasing doses of annona muricata extract,caspase-9 activity also increase that effect in tubular cell and damage its structure.

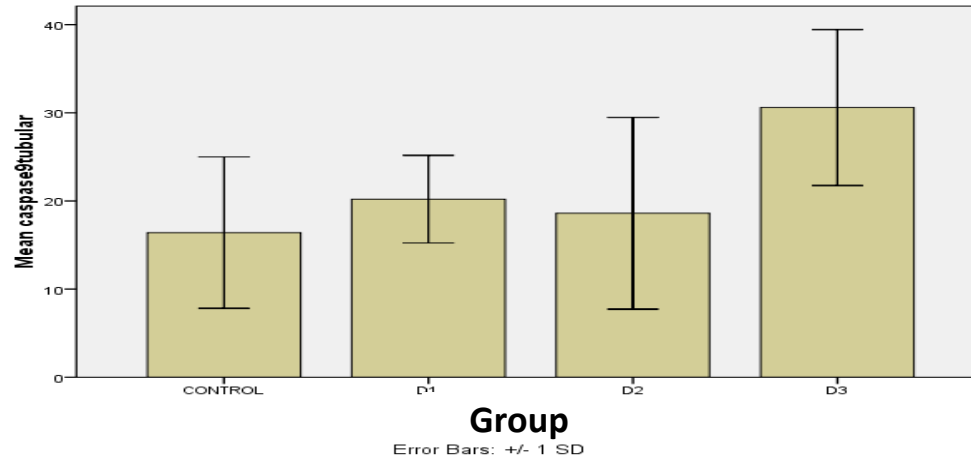

Control : control group with normal saline

Group I : annona muricat extract with doses $10 \mathrm{mg} / \mathrm{kg} . \mathrm{bw} / \mathrm{day}$

Group II : annona muricat extract with doses $20 \mathrm{mg} / \mathrm{kg} . \mathrm{bw} / \mathrm{day}$

Group III : annona muricat extract with doses $40 \mathrm{mg} / \mathrm{kg} \cdot \mathrm{bw} / \mathrm{day}$

\subsection{Effect of Different Doses of Annon Muricata Extract on Account Of caspase-9 in Glomerulus cell}

In the figure 7 below, for all doses of annona muricata extract we found decrease of caspase- 9 in glomerulus cell. 


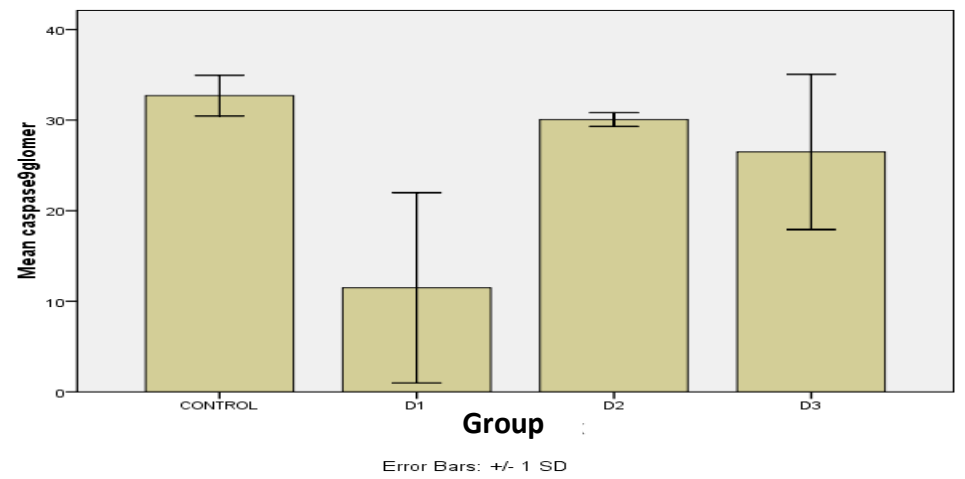

Control : control group with normal saline

Group I : annona muricat extract with doses $10 \mathrm{mg} / \mathrm{kg} . \mathrm{bw} / \mathrm{day}$

Group II : annona muricat extract with doses $20 \mathrm{mg} / \mathrm{kg} . b w /$ day

Group III : annona muricat extract with doses $40 \mathrm{mg} / \mathrm{kg} . b w /$ day

\section{Discussion}

Annona muricata extract has the potential to causes damage to the kidney cell and function by prolonged exposure. The male kidney organs are severely damaged at doses $40 \mathrm{mg} / \mathrm{kg} . \mathrm{bw}$ in mice. The effects include increase in creatinine serum concentration and damage structure tubular. It has been shown to produce developmental toxicity in several doses, which cause kidney damage leading to renal failure.

We note that group III, Which treated by $40 \mathrm{mg} / \mathrm{kg}$ body weight/day annona muricata extract has the highest rate of effect compared to other groups, followed by group C, and B. This means the annona muricata extract at high dose lead to high increase on creatinine serum concentration and on the histological tubular structure. where the effect on tubular cell at high dose of annona muricata led to damaging in structure and this seen in microscope more when the dose increased. On premises inspection microscope is seen that with increasing the dose , the tubular cell damage will be even greater(Arthur,at al; 2011).

Were observed in creatinine concentration at higher doses which suggest a possible kidney damage, especially by renal infiltration mechanism(Wasan,at al; 2001).

Earlier reports have shown that if the median lethal dose of a test substance is three times more than the minimum effective dose, the substance is considered a good candidate for further studies(Salawu, at al; 2009). The leaf extract is therefore safe for oral use for the management of several diseases(Walum 1998).

The annona muricata extract, as directed by ethno medicinal use in Ghana, Indonesia it is contained polar extracts which are responsible for therapeutic effect. Photochemical analysis helps detect the chemical constituents of plants extract in search of bioactive agents as basis for drug synthesis(Ogbonnia et al; 2009).

As it is clear from the results of this study that the administration of annona muricata extract indicated histological changes in kidney cell and this change lead to effect in tubular structure causing to kidney damage in higher doses.

\section{Conclusion}

It is concluded from present study that use of medicinal plant Annona muricata at the dose of 10, 20, and $40 \mathrm{mg} / \mathrm{kg}$ body weight in saline orally for 40 days it cause kidney damage leading to renal failure. Thus for long term usage, kidney function should be monitored.

The need to evaluate the toxicity profile of Annona muricata leaf extract was prompted by the increasing awareness and interest in medicinal plants and their preparations commonly known as herbal medicine. Consequently, herbal medicines have received greater attention as alternatives to orthodox therapy, leading to their increase in demand.

\section{Acknowledgements}

The authors acknowledge the technical assistance of Mis. Ferrida,sp and Mr. Mohamad abuhari (Department of Pharmacology), Mr.Lasmizan,SE (Pathology Anatomy Laboratory), Mr. Wibi Riawan and Mis. Ami maghfironi (Biochemistry Laboratory), Mis. Analis (Prima laboratory), Mr. Satuman S.Si., M.Kes (Physiology laboratory)

\section{References}


[1] Adewole, S.O. and J.A. Ojewole, 2008. Protective effects of Annona muricata Linn. (Annonaceae) leaf aqueous extract on serum lipid profiles and oxidative stress in hepatocytes of streptozotocin- treated diabetic rats. Afr. J. Trad. Complement Altern Med., 6: 30-41. PMID: 20162039

[2] Adewole, S.O. and J.A.O. Ojewole, 2006. Immunohistochemcal and biochemical effects of Annona muricata Linn. (Annonaceae) leaf aqueous extract on pancreatic $\beta$-cells of streptozotocin-treated diabetic rats. Pharmacologyonline, 2: 335-355.

[3] Alali, F.Q., X.X. Lui and J.L. McLaughlin, 1999. Annonaceous acetogenins: Recent progress. J. Nat. Prod., 62: 504-540. PMID: 10096871 .

[4] Arthur, F.K.N., E. Woode, E.O. Terlabi and C. Larbie, 2011. Evaluation of acute and subchronic toxicity of Annona Muricata (Linn.) Aqueous extract in animals. Eur. J. Exp. Biol., 1: 115-124.

[5] Bailey C. J., Day C. (1989): Traditional plant medicines as treatment for diabetes. Diabetes Care; 12, 553-564. Keen R. W., Deacon A. C., Delves H. T., Moreton J. A., Frost P. G. (1994): Indian herbal remedies for diabetes as a cause of lead poisoning. Postgrad Med J 70, 113-114.

[6] Duke, J.A., 1970. Ethnobotanical observations on the Chocó Indians. Econ. Botany, 24: 344-366. DOI: 10.1007/BF02860669.

[7] Gleye, C., P. Duret, A. Laurens, R. Hocquenniller and O. Laprevote, 1998. Cis Monotetrahydrofuran acetogenins from the roots of Annona muricata. J. Nat. Prod., 61: 576-579. DOI: 10.1021/np970494m

[8] ICUC, 2002. Fruits of the future Annona. International Centre for Underutilized Crops.

[9] Kim, G.H., L. Zeng, F. Alali, L.L. Rogers and F.E. Wu et al., 1998. Muricoreacin and murihexocin C, mono-tetrahydrofuran acetogenins, from the leaves of Annona muricata in honour of Professor G.H. Neil Towers 75th birthday. Phytochemistry, 49: 565571. DOI: 10.1016/S0031-9422(98)00172-1.

[10] Khan, M.R., K. Kornine and A.D. Omoloso, 1997. Antibacterial activity of some Annonaceae Part 1. Fitoterapia, 69: $367-369$.

[11] Morgan M., Watkins C. J. (1988): Managing hypertention: beliefs and responses to medication among cultural groups. Sociol Health Illn, 10, 561- 578 .

[12] Mshana, N.R., D.K. Abbiw, I. Addae-Mensah, E. Adjanouhoun and M.R. Ahyi et al., 2000. Traditional Medicine and Pharmacopoeia: Contribution to the Revision of Ethnobotanical and Floristic Studies in Ghana. 1st Edn., OAU/STRC, Accra, pp: 920 .

[13] Ogbonnia SO, Nkemehule FE and Anyika EN. 2009. African Journal of Biotechnology; 8(9): 1793 - 1799.

[14] Salawu OA, Chindo BA, Tijani AY, Obidike IC, Salawu TA and Akingbasote AJ. 2009. African Journal of Pharmacy and Pharmacology; 3 (12): $621-626$.

[15] Walum E. 1998. Environmental Health Perspectives; 106 (2): 497-502.

[16] Wasan KM, Najafi S, Wong J and Kwong M. 2001. J. Pharm. Sci.; 4 (3): 228 - 233.

[17] Wu, F.E., Z.M. Gu, L. Zeng, G.X. Zhao and Y. Zhang, et al., 1995. Two new cytotoxic monotetrahydrofuran annonaceous acetogenins, annomuricins A and B, from the leaves of Annona muricata. J. Nat. Prod., 58: 830-836. DOI: 10.1021/np50120a002.

[18] Zeng, L., F.E. Wu, N.H. Oberlies and J.L. McLaughlin, 1996. Five new mono tetra hydro furan ring acetogenins from the leaves of Annona muricata. J. Nat. Prod., 59: 1035-1042. DOI: 10.1021/np960447e 